\section{UIT DE ECONOMIST VAN 1859}

\section{ECONOMISCHE KRONIJK (17 Mei)}

De gewone gevolgen van den oorlog zijn reeds van alle zijde waar te nemen; duurte van levensmiddelen, duurte van geld; al de artikelen die onmiddellijk tot de krijgvoering zelve benoodigd zijn, als graan, leder, salpeter, zwavel, steenkool, metalen, zijn in prijs gestegen, terwijl weelde-artikelen dalen. De groote dépots door vele regeringen voor hunne legerbehoeften aangelegd, hebben de graanprijzen sterk doen rijzen. In Engeland, in Frankrijk en vele hoofdmarkten van het vasteland, was de rijzing van de tarwe op het eind van April reeds f 1,50 à $f$ per mud.

[.... Die algemeene rijzing der noodzakelijke voedingsmiddelen wordt door een even algemeene daling in den koers der effecten en rijzing in de handels-interest vergezeld.
FROM DE ECONOMIST OF 1859

\section{ECONOMIC CHRONICLE (17 May)}

The usual effects of war have manifested themselves already in all aspects; expensiveness of food and provisions, of money; prices of all commodities directly required for warfare itself, such as corn, leather, nitrite, sulphur, coal and metals, rose, while those of luxury goods fell. Large depots installed by many governments to meet their armies' needs have led to rising corn prices. By the end of April, in England and France, and in many key markets on the continent, wheat was up by 1.5-2 Guilders per hectolitre.

[.... The widespread rise of food prices has been accompanied by an equally general fall in equity prices and increase in interest rates. 